\title{
Prevalence of the metabolic syndrome and associated lifestyles in adult males from Oaxaca, Mexico
}

\author{
Estanislao Ramírez-Vargas, PhD Candidate, ${ }^{(1,2)}$ María del Rosario Arnaud-Viñas, PhD, ${ }^{(3)}$ \\ Hélène Delisle, $\mathrm{PhD}{ }^{(4)}$
}

\section{Ramírez-Vargas E, Arnaud-Viñas MR, Delisle H. Prevalence of the metabolic syndrome and associated lifestyles in adult males from Oaxaca, Mexico. Salud Publica Mex 2007;49:94-102.}

\begin{abstract}
Objective.To determine the associations of metabolic syndrome (MS) with residential area and lifestyle in men from Oaxaca, Mexico. Material and Methods. A cross-sectional study was conducted in 1998 in 325 apparently healthy men 35 to 65 years of age in four residential areas: rural, urban poor, urban middle, and urban rich. MS was defined according to International Diabetes Federation (IDF) guidelines. Information on physical activity and diet was collected by questionnaire. Based on two 24-hour recalls, a diet quality index (DQI) using eightWHO recommendations to prevent chronic diseases was constructed. Results. The MS rate was $41.2 \%$; twice as high in urban (45.4\%) than rural $(27.6 \%)$ subjects.A significantly higher risk of $\mathrm{MS}$ was associated with low DQI in urban poor (OR 2.5; Cl: I.0-6.3) and rich (OR 3.2; Cl: I.5-8.6), compared to rural subjects. Physical activity was an independent protective factor. Conclusions. MS is highly prevalent in apparently healthy men in urban areas, illustrating the role of diet and lifestyle transition.
\end{abstract}

Key words: metabolic syndrome; IDF definition; cardiovascular risk factors; nutrition transition; lifestyle; Mexico
Ramírez-Vargas E, Arnaud-Viñas MR, Delisle H.

Prevalencia del síndrome metabólico y su asociación con estilo de vida en hombres adultos de Oaxaca, México. Salud Publica Mex 2007;49:94-102.

\section{Resumen}

Objetivo. Determinar las asociaciones entre el síndrome metabólico (SM) con el área residencial y el estilo de vida en hombres de Oaxaca, México. Material y métodos. Estudio transversal en 325 adultos en cuatro áreas residenciales: rural y urbano (pobre, medio y rico), realizado en 1998. Se utilizó la definición de IDF para SM y documentó la actividad física y dieta. Con base en dos recordatorios de 24-horas, se construyó un índice de calidad nutricional (ICN) utilizando ocho recomendaciones de la OMS para la prevención de enfermedades crónicas. Resultados. La prevalencia general del SM fue de $41.2 \%$, y doblemente mayor en urbanos ricos (45.4\%) que en rurales (27.6\%). Un riesgo significativamente más elevado de SM se asoció con un ICN bajo en urbanos pobres y en sujetos ricos (OR 3.2; IC: I.5-8.6). La actividad física fue un factor protector independiente. Conclusiones. EI SM es altamente prevalente en hombres aparentemente sanos en áreas urbanas, lo cual refleja el papel de la transición nutricional y del estilo de vida.

Palabras clave: síndrome metabólico; definición IDF; factores de riesgo cardiovascular; transición nutricional; estilo de vida; México

(I) Zone I General Hospital, Mexican Institute of Social Security. Oaxaca, Mexico.

(2) Research Center of Medical and Biological Sciences, UABJO School of Medicine. Oaxaca, Mexico.

(3) Director, Inter-disciplinary Investigation Center for Regional Integral Development, National Polytechnology Institute. Oaxaca, Mexico.

(4) Director,WHO Collaborating Centre on Nutrition Changes and Development (TRANSNUT). Department of Nutrition, School of Medicine University of Montreal, Canada. 
$\mathbf{M}$ etabolic syndrome (MS) is a clustering of cardiovascular risk factors, i.e. abdominal obesity, low high-density lipoprotein (HDL) cholesterol, elevated triglycerides, hyperinsulinemia, hyperglycemia and hypertension. ${ }^{1,2}$ The first official definition of MS was introduced by an expert panel of the World Health Organization in $1998 .{ }^{3}$ Subsequently, the National Cholesterol Education Program's Adult Treatment Panel III (NCEP: ATP III) ${ }^{4}$ and the EGIR (European Group for the Study of Insulin Resistance $)^{5}$ have formulated slightly different definitions. A more recent definition is that proposed by the International Diabetes Federation (IDF). ${ }^{6}$ All of these agree on essential components, that is, dysglycemia or glucose intolerance, obesity, hypertension, and dyslipidaemia, but they do differ in the cut-off criteria and consequently, MS rates vary according to the definition used. Only WHO, however, includes insulin resistance, assessed using the clamp method, as a criterion. The definition of IDF uses abdominal obesity based on waist circumference as a core component of MS. The principal reason for this first criterion is that abdominal obesity is independently associated with every other MS component including insulin resistance. ${ }^{7,8}$ While the latter is expensive and technically difficult to measure, the former is easily assessed. The IDF stated that this new definition, which emphasizes the importance of central obesity with cutoffs adapted to ethnic group, would be adopted worldwide, as it proves convenient and useful in clinical practice and epidemiological studies.

The etiology of MS is not yet understood, but presumably represents a complex interaction between genetic, metabolic and behavioural factors, such as diet and physical activity. ${ }^{9,10}$ There is also evidence that undernutrition during foetal life and early childhood may cause permanent changes in human metabolism and thus affect the development of the metabolic syndrome in later life. ${ }^{11}$ A sedentary lifestyle and the lack of physical activity are important factors in the development of the syndrome. ${ }^{12,13}$ Total physical energy expenditure and fitness (measured as maximal oxygen consumption) have independent effects on MS components. ${ }^{14}$

The Mexican National Survey of Health 2000 (ENSA $)^{15}$ contributes very important data on the high prevalence of markers of cardiovascular disease (CVD) risk: in the adult population (age 20 years and above), the prevalence of diabetes was $7.5 \%$, hypertension $30.7 \%$, and obesity $23.7 \% .{ }^{15}$ Diabetes and CVD are now the first causes of death in Mexico. ${ }^{16}$

The morbidity and mortality profile of Mexico has been changing in the last decades because of the epi- demiological and nutritional transition..$^{16-17}$ In Mexico, as well as other similar countries of Latin America, a phenomenon of epidemiological polarization is observed, meaning that developed industrial states of northern Mexico have an epidemiological profile similar to that of developed countries; in contrast, less developed southern states (including Oaxaca state) reflect less advanced transitional epidemiological profiles. ${ }^{17,18}$ The global burden of disease among poor people includes increased diabetes and other noncommunicable chronic diseases in addition to infection and communicable diseases. ${ }^{19,20}$

Urbanization usually means increased access to energy-dense industrialized foods, which may have an adverse effect on dietary patterns with metabolic consequences, particularly for underserved vulnerable populations. ${ }^{21}$ Furthermore, rapid urbanization is accompanied by technological changes -in work and transportation- leading to reduced physical activity in the working place and leisure time, as well as to changes in food patterns. ${ }^{22}$

Our objective is to describe the association of MS with residential area as an indicator of socio-economic status and lifestyle patterns (physical activity, smoking and diet) in apparently healthy men from Oaxaca, Mexico.

\section{Material and Methods}

This descriptive, cross-sectional study was conducted in rural and urban areas of Oaxaca, Mexico. We randomly selected 325 apparently healthy men between 35 and 65 years of age. All the subjects with medical diagnosis of metabolic disease or another serious disease were excluded from the study. The sample size was determined considering a prevalence of $15 \% \mathrm{MS},{ }^{23}$ and a marginal error of $4 \%$, with a level of confidence of $95 \%$. The sample was stratified by residential area. The urban population selection was done by consulting the municipal database of Oaxaca and the classification of residential area by cadastral payment in three categories (poor, middle and rich neighborhood). A rural area in the central valley of Oaxaca was also selected, by consulting the XI census of the National Institute of Statistics and Geography of Mexico. ${ }^{24}$ Three towns were selected at random among those with less than 2500 inhabitants, the urban-rural cut-off ${ }^{25}$ value (San Javier, San Raymundo Jalpan and San Juan de Dios). Rich proprietors of farms were excluded.

The study was approved by the Committee of Research and Ethics of the Oaxaca Delegation of the Me- 
xican Institute of the Social Security and by the Hospital Center of the Université de Montréal (CHUM), Canada. All subjects signed the informed consent form.

\section{Operational definitions}

Metabolic syndrome (MS) was defined according to IDF guidelines: ${ }^{6}$ central obesity (defined as waist circumference $\geq 94 \mathrm{~cm}$ ), plus any two of the following factors: triglycerides (TG) $\geq 150 \mathrm{mg} / \mathrm{dL}(1.7 \mathrm{mmol} / \mathrm{L})$, HDL-Cholesterol (HDL-C) $<40 \mathrm{mg} / \mathrm{dL}(<1.03 \mathrm{MMOL} /$ 1), systolic blood pressure (SBP) $\geq 130$ or diastolic (DBP) $\geq 85 \mathrm{~mm} \mathrm{Hg}$, and fasting plasma glucose $\geq 100 \mathrm{mg} / \mathrm{dL}$ (5.6 mmol/L).

Insulin resistance was calculated by Homeostatic Model Assessment (HOMA): glucose (mg/dL) X insulin $(\mathrm{mU} / \mathrm{mL}) / 405 .{ }^{26}$ Insulin resistance was considered at values $\geq 2.68$, based on data for the USA population. ${ }^{27}$

\section{Biological and biochemical parameters}

Anthropometric measurements: Height and weight were measured in light clothing. Body mass index (BMI) was computed as weight $(\mathrm{kg}) /$ height $(\mathrm{m}){ }^{2}$. Waist circumference (WC) was measured at mid-point between the lower costal margin and the level of the anterior superior iliac crest; a flexible clinical measuring tape was used. Sitting systolic (SBP) and diastolic (DBP) blood pressures were measured using a standard sphygmomanometer. Two readings were obtained and averaged at 5-minute intervals.

The blood samples were collected in all subjects after an overnight fast of at least 12 hours. Glucose was measured using the glucose-oxidase method. TG and cholesterol were measured using a kit of enzymatic reagents. HDL-C was measured after precipitation of lipoproteins that contain apoprotein B with phosphotungstate and magnesium chloride. The kits and reagents were obtained from Boehringer Mannheim, (Germany). Insulin was measured by the method of chemiluminescence with reagents of Diagnostic Products Corporation (DPC, Los Angeles, CA, USA).

A questionnaire was administered to collect data on lifestyle and family history of diabetes and hypertension. For physical activity, we used a questionnaire validated in Canada but not in the study population. ${ }^{28}$ Four aspects were considered: means of transportation to go to work; physical activity level of the main occupation; leisure sport activity; and time spent watching television. We also documented tobacco consumption. Other data included family history of hypertension and diabetes.

A score of physical activity was created considering four variables with four levels each: 1) means of transportation (walking, bicycle, motorcycle, automobile); 2) physical activity level for main occupation (sitting; standing and walking; carrying light load /climbing stairs; heavy work); 3) sport (none or rarely, 2-3 times/month, 1-2 times/week, and $\geq 3$ times/week); and 4) hours/week watching television ( $\geq 13,8-12,4-7$ and $\leq 3)$. For each item, the lowest level of physical activity was assigned the value of 1 , with a maximum of 4 assigned to the highest level. The maximum physical activity score was 16; computed scores ranged between 4 and 15. Score tertiles $(\leq 7,8-10$ and $\geq 11)$ were used in the analyses. Daily cigarette consumption was also categorized (0-5 and $\geq 6$ ). Dietary intake was assessed using two nonconsecutive 24-hour recalls. ${ }^{29} \mathrm{~A}$ diet quality index, or "preventive" score was constructed on the basis of eight recommendations of the FAO/OMS Committee of Experts for the prevention of chronic diseases. ${ }^{30}$ The positive components of the index are: daily consumption of $\geq 400 \mathrm{~g}$ fruits and vegetables; protein $\geq 10 \%$ total energy; total fat $<30 \%$ total energy; saturated fat $<10 \%$ total energy; polyunsaturated fat $6-10 \%$ total energy; cholesterol $<300 \mathrm{mg}$; sucrose $<300 \mathrm{mg}$; and total dietary fibre $\geq 25 \mathrm{~g}$. Compliance with each item was assigned a value of 1 and non-compliance, a value of 0 . The maximum value for the index was 8 . Observed values ranged between 2 and 8 . Index tertiles were used in the analyses (2-4, 5-6 and 7-8), corresponding to low, medium and high dietary preventive score.

\section{Statistical analysis}

Analysis of data was done with SPSS/PC statistical analysis software, version 11 for Windows (SPSS, Chicago, IL). The Chi-square test was used to analyze the statistical differences among proportions for the characteristics of the study participants. One-way ANOVA was used to assess the differences in physical and biochemical parameters in the four residential areas. Logistic regression models were used to estimate the odds of MS according to residential area, diet quality, physical activity and smoking habits. Crude and adjusted (for age and family history of diabetes and hypertension) odds ratios (OR) and confidence intervals (95\% $\mathrm{CI}$ ) are described. An explicative multivariate logistic regression model of MS on independent variables also included the interaction between residential area and diet quality score, where the reference category was subjects living in rural areas and those with a high "preventive" diet score. Control variables were age, and family history of diabetes and hypertension.

The area under curve ROC is described, with a cutoff point of 0.5 to obtain the sensitivity and the specificity of the fit model. To evaluate goodness of fit, we included the value (p) of Hosmer and Lemeshow test to models I, 
II and III. In the multiple logistic regression model with interactions, we report adjusted odds ratios. ${ }^{31}$

\section{Results}

According to the IDF definition, the overall MS prevalence was $41.2 \%$. The mean age of subjects with and without MS was similar: 49.0 years (S.E. 0.80 ) and 49.3 years (S.E. 0.67).

Physical and metabolic characteristics of subjects according to residential area are shown in Table I. The highest weight, height, body mass index (BMI), waist circumference (WC) and diastolic blood pressure (DBP) were observed in the rich urban group $(p<0.005)$, while the lowest insulin, HOMA, triglycerides (TG) and LDL$\mathrm{C}$ levels were observed in the rural group. The latter group also showed the highest HDL-C and glycemia concentrations (Table I).

Mean BMI in rural and urban groups was $24.9 \pm 3.6$ and 27.1 \pm 4.6 , respectively. The prevalence of obesity (BMI $\geq 30$ ) was $9.3 \%$ in rural subjects, $25.9 \%$ in urban poor, $33.3 \%$ in urban middle and $31.5 \%$ in urban rich neighborhoods $(p=0.014)$.

The overall prevalence of abdominal obesity was $51.7 \%$; that of glycemia $\geq 100 \mathrm{mg} / \mathrm{dL}$ was $26.8 \%$; TG $\geq 150$ $\mathrm{mg} / \mathrm{dL}$ was 59.1\%; HDL-C <40mg/dL, 52.3\%; SBP $\geq 130$ $\mathrm{mm} \mathrm{Hg}, 61.5 \%$; and DBP $\geq 85 \mathrm{~mm} \mathrm{Hg}, 61.8 \%$. Rural and poor urban groups showed the highest prevalence of disglycemia $(38.2 \%$ and $31.7 \%$, respectively, $p<0.005)$.
Urban poor and rich groups showed the highest prevalence of TG $\geq 150 \mathrm{mg} / \mathrm{dL}$ (58.7\% and $57.4 \%$, respectively), while the rural group showed a prevalence of $43.4 \%$ $(p=0.037)$. Urban poor and rich groups also showed the highest prevalence of HDL-C $<40 \mathrm{mg} / \mathrm{dL}(58.7 \%$ and $64.7 \%$, respectively), while it was $44.7 \%$ in the rural subjects $(p=0.037)$. The rate of high diastolic blood pressure $(\geq 85 \mathrm{~mm} \mathrm{Hg})$ among urban poor and rich groups was $71.4 \%$ and $72.1 \%$, respectively. There was no significant difference between the high diastolic and systolic blood pressure groups.

Abdominal obesity is the core abnormality for MS according to the IDF definition. Its prevalence (WC $\geq 94$ $\mathrm{cm}$ ) and the number of additional markers of MS by residential area are shown in Table II. Abdominal obesity was highest in urban rich (70.6\%) and there was a downward gradient, with $55.6 \%$ in the urban poor, $49.2 \%$ in the middle urban group, and $35.5 \%$ in the rural group ( $p<0.0001)$. MS, that is, abdominal obesity plus two other abnormalities, was present in $54.4 \%$ of the urban rich, $50.8 \%$ of the urban poor, and it was lower in the middle urban group (37.2\%) and in the rural subjects $(27.6 \%)(p<0.006)$.

MS was significantly associated with having a family history of diabetes and hypertension, as well as with residential area and physical activity (Table III). However, diet quality was not significantly different between subjects having or not having MS. We found a trend for less smoking among subjects without MS. The

Table I

Physical and metabolic characteristics according to groups defined by pLaCe of Residence, in 325 men of OAXaca, 1998. CRude MeAn ANd Standard error

\begin{tabular}{|c|c|c|c|c|c|}
\hline Parameters & Rural (a) (n=76) & Urban Poor (b) $(n=63)$ & Urban Middle (c) $(n=\mid / 8)$ & Urban Rich (d) $(n=68)$ & $p^{*}$ \\
\hline \multicolumn{6}{|l|}{ Physical } \\
\hline Height (cm) & $157.7(0.70)^{\mathrm{a} \ddagger}$ & $161.4(0.67)^{\mathrm{b}}$ & $163.0(0.62)^{\mathrm{bc}}$ & $168.1(0.78)^{d}$ & $<0.0001$ \\
\hline $\mathrm{BMI}\left(\mathrm{kg} /(\mathrm{m})^{2}\right)$ & $24.8(0.42)^{\mathrm{a}}$ & $27.1 \quad(0.57)^{b}$ & $27.2(0.37)^{\mathrm{bc}}$ & $28.0(0.54)^{d}$ & $<0.0001$ \\
\hline $\mathrm{WC}(\mathrm{cm})$ & $89.5(1.19)^{\mathrm{a}}$ & $95.5(1.37)^{b}$ & $95.3(0.93)^{b c}$ & $100.0(1.34)^{d}$ & $<0.0001$ \\
\hline $\mathrm{SBP}(\mathrm{mm} \mathrm{Hg})$ & $135.2(2.14)$ & $136.9 \quad(2.68)$ & $132.5(1.86)$ & $134.0(2.36)$ & 0.548 \\
\hline $\mathrm{DBP}(\mathrm{mm} \mathrm{Hg})$ & $85.6(0.91)^{\mathrm{a}}$ & $89.7(1.33)^{\mathrm{ab}}$ & $86.7(1.00)^{a b c}$ & $91.0(1.46)^{d}$ & 0.005 \\
\hline \multicolumn{6}{|l|}{ Metabolic } \\
\hline Glycemia (mg/dL) & $103.9(4.23)$ & $101.5 \quad(5.36)$ & $92.2(2.4 I)$ & $96.4 \quad(3.05)$ & 0.067 \\
\hline Insulin $(\mu \mathrm{U} / \mathrm{ml})$ & $8.8(0.7 I)^{\mathrm{a}}$ & I5.I $(2.90)^{\mathrm{ab}}$ & $16.7(I .83)^{b c}$ & $13.7(0.92)^{\mathrm{abcd}}$ & 0.012 \\
\hline HOMA & $2.2(0.20)$ & $3.8(0.87)$ & $3.8(0.48)$ & $3.4(0.28)$ & 0.094 \\
\hline TG (mg/dL) & $155.5(7.65)$ & $208.0(23.47)$ & $207.6(14.19)$ & $200.4(15.54)$ & 0.058 \\
\hline HDL-C (mg/dL) & $44.0(1.49)$ & $39.3(\mathrm{I} .6 \mathrm{I})$ & $43.9(1.45)$ & $40.0 \quad(1.47)$ & 0.062 \\
\hline LDL-C (mg/dL) & $102.7(2.47)^{\mathrm{a}}$ & $115.0(4.49)^{\mathrm{ab}}$ & $119.0(3.49)^{\mathrm{bc}}$ & $126.8(4.64)^{b c d}$ & $<0.0001$ \\
\hline
\end{tabular}


Table II

Prevalence of abdominal obesity (WAist Circumference $\geq 94 \mathrm{~cm}$ ) AND other markers

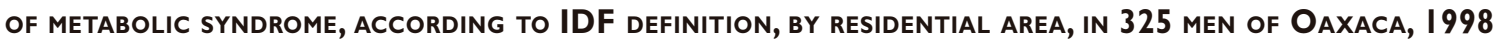

\begin{tabular}{|c|c|c|c|c|c|c|}
\hline Parameters & $\begin{array}{c}\text { Rural }(n=76) \\
(\%)\end{array}$ & $\begin{array}{c}\text { Urban poor }(n=63) \\
(\%)\end{array}$ & $\begin{array}{c}\text { Urban middle }(\mathrm{n}=\mid \mathrm{I}) \\
(\%)\end{array}$ & $\begin{array}{c}\text { Urban rich }(\mathrm{n}=68) \\
(\%)\end{array}$ & $\begin{array}{c}\text { Total }(n=325) \\
(\%)\end{array}$ & $p^{*}$ \\
\hline$W C \geq 94 \mathrm{~cm}$ & 35.5 & 55.6 & 49.2 & 70.6 & 51.7 & $<0.0001$ \\
\hline \multicolumn{7}{|c|}{ Waist circumference + number of markers } \\
\hline$W C \geq 94 \mathrm{~cm}$ only & 2.6 & 0 & 2.5 & 1.5 & 1.8 & 0.006 \\
\hline$W C \geq 94 \mathrm{~cm}+1$ & 5.3 & 4.8 & 9.3 & 14.7 & 8.6 & \\
\hline$W C \geq 94 \mathrm{~cm}+2$ & 9.2 & 23.8 & 14.4 & 20.6 & 16.3 & \\
\hline$W C \geq 94 \mathrm{~cm}+3$ & 14.5 & 19.1 & 19.4 & 19.1 & 18.2 & \\
\hline$W C \geq 94 \mathrm{~cm}+4$ & 3.9 & 7.9 & 3.4 & 14.7 & 6.8 & \\
\hline$W C<94 \mathrm{~cm}$ & 64.5 & 44.4 & 50.8 & 29.4 & 48.3 & \\
\hline MS & 27.6 & 50.8 & 37.2 & 54.4 & 41.2 & 0.003 \\
\hline
\end{tabular}

relative rate of MS (adjusted for age, family history of diabetes and hypertension) according to residential area and lifestyle is shown in Table IV. We observed a significantly higher adjusted rate of MS in subjects living in urban areas compared to those living in rural areas, excluding the intermediate neighborhood group. Physical activity was a protective factor, particularly for the higher score level $(p<0,001)$. Diet quality and smoking status were not significant, even if we observed a trend of higher risk of MS among subjects with low preventive diet score (Table IV).

The results of the multiple logistic regression for the estimation of MS risk according to family history of diabetes, residence area, and lifestyle, adjusting by age and family history of hypertension, are shown in Table V. A family history of diabetes was another risk factor independently associated to MS (Table V). There was a significant interaction between residence area and diet quality. When considering as reference the rural subjects with a high preventive diet score, urban poor and rich neighborhood subjects with low diet quality (preventive score) had a significantly higher risk of MS; a trend was also observed for medium diet quality. Physical activity was an independent protective factor, particularly at score level $\geq 11$ compared to score level $\leq 7$. Tobacco smoking was not significant.

\section{Discussion}

The overall prevalence of MS among adult men from Oaxaca was higher than in Mexican-Americans (41.2\% vs $31.9 \%$, respectively), who have the highest prevalence of MS in the USA. ${ }^{32}$ Using the NCEP ATP-III definition,

\section{Table III}

Age, FAMILY HISTORY AND LIFESTYLE OF SUBJECTS WITH (+) AND WITHOUT (-) METABOLIC SYNDROME; 325 MEN OF OAXACA, 1998

\begin{tabular}{ccccc} 
Parameters & $\begin{array}{c}\text { Total } \\
(n=325) \\
(\%)\end{array}$ & $\begin{array}{c}\text { MS }(+) \\
(n=123) \\
(\%)\end{array}$ & $\begin{array}{c}\text { MS (-) } \\
(n=202) \\
(\%)\end{array}$ & $p^{*}$ \\
$\begin{array}{c}\text { Age (years) } \\
35-44\end{array}$ & 36.9 & 37.3 & 36.6 & 0.317 \\
\hline $45-54$ & 35.1 & 38.8 & 32.5 & \\
\hline$\geq 55$ & 28.0 & 23.9 & 30.9 &
\end{tabular}

Family history

\begin{tabular}{lcccc} 
Diabetes mellitus & 35.7 & 47.0 & 27.7 & $<0.000$ I \\
\hline Hypertension & 38.9 & 45.5 & 34.2 & 0.026 \\
$\begin{array}{l}\text { Residential area } \\
\text { Rural }\end{array}$ & 23.4 & 15.7 & 28.8 & 0.003 \\
\hline Urban poor & 19.4 & 23.9 & 16.2 & \\
\hline Urban middle & 36.3 & 32.8 & 38.7 & \\
\hline Urban rich & 20.9 & 27.6 & 16.2 &
\end{tabular}

Diet quality index

\begin{tabular}{lllll} 
High $(7-8)$ & 18.5 & 15.7 & 20.4 & 0.269 \\
\hline Average $(5-6)$ & 44.0 & 38.1 & 37.2 & \\
\hline Low $(2-4)$ & 37.5 & 46.3 & 42.4 &
\end{tabular}

Physical activity score

\begin{tabular}{lllll} 
Low $(\leq 7)$ & 27.7 & 35.8 & 22.0 & 0.001 \\
\hline Average $(8$ to I0) & 47.7 & 49.3 & 46.6 & \\
\hline High $(\geq 1 \mathrm{II})$ & 24.6 & 14.9 & 31.4 &
\end{tabular}

Tobacco

\begin{tabular}{lrrrr}
$0-5$ cigarettes/day & 95.1 & 92.5 & 96.9 & 0.065 \\
\hline 6 cigarettes/day & 4.9 & 7.5 & 3.1 & \\
$\chi^{2}$ test & & & &
\end{tabular}


Table IV

\section{LiKeliHOOd OF METABolic SYNDROOME ACCORDING to RESIDENTIAL AREA AND LIFESTYLe, IN 325 MEN OF OAXACA, I998}

Factors $\quad$ Total $(n) \quad$ Odds ratio $(\mathrm{OR})$, crude $(95 \% \mathrm{Cl}) \quad p \quad$ OR, adjusted* $(95 \% \mathrm{Cl}) \quad p$

\begin{tabular}{lcllll}
$\begin{array}{l}\text { Residential area } \\
\text { Rural }\end{array}$ & 76 & 1.00 & & 1.00 & \\
\hline Urban poor & 63 & $2.70(1.34,5.47)$ & 0.006 & $2.33(1.12,4.82)$ & 0.023 \\
\hline Urban middle & 118 & $1.56(0.83,2.91)$ & 0.166 & $1.27(0.65,2.45)$ & 0.486 \\
\hline Urban rich & 68 & $3.13(1.36,6.25)$ & 0.001 & $2.59(1.26,5.34)$ & 0.010
\end{tabular}

Diet quality index

\begin{tabular}{llllll} 
High (7-8) & 60 & 1.00 & \multicolumn{3}{l}{1.00} \\
\hline Average (5-6) & 143 & $1.33(0.70,2.50)$ & 0.278 & $1.20(0.72,1.97)$ & 0.386 \\
\hline Low $(2-4)$ & 122 & $1.42(0.76,2.66)$ & 0.170 & $1.43(0.75,2.71)$ & 0.176
\end{tabular}

Physical activity Score

\begin{tabular}{|c|c|c|c|c|c|}
\hline Low $(\leq 7)$ & 90 & 1.00 & & 1.00 & \\
\hline Average (8 to 10$)$ & 155 & $0.65(0.39,1.09)$ & 0.105 & $0.70((0.41,1.19)$ & 0.188 \\
\hline High $(\geq I I)$ & 80 & $0.29(0.15,0.56)$ & $<0.001$ & $0.32(0.16,0.34)$ & 0.001 \\
\hline \multicolumn{6}{|l|}{ Tobacco } \\
\hline $0-5$ cigarettes/day & 309 & 1.00 & & 1.00 & \\
\hline$\geq 6$ cigarettes/day & 16 & $2.49(0.88,7.02)$ & 0.085 & $1.78(0.6 \mathrm{I}, 5.22)$ & 0.291 \\
\hline
\end{tabular}

Aguilar-Salinas et al. ${ }^{33}$ found a national MS prevalence of $26.6 \%$ in Mexican men and women aged 20-69 years. In a recent population-based study in Mexico City, a higher MS prevalence rate was observed (39.9\%). ${ }^{34}$ The prevalence of MS in the present study is high but no previous studies on MS in rural or urban areas in Oaxaca are available for comparison.

We found a significant association between family history of type 2 diabetes and MS. A family history of diabetes is a marker of genetic predisposition to components of MS, as shown by Hunt et al. ${ }^{35}$ who reported that in non-obese subjects, the odds ratios were 2.5 (95\% CI:1.1-6.1) and 2.9 (95\% CI:1.2-7.0) for history of diabetes and hypertension. These and other results may imply that family history is associated with the development of MS. ${ }^{36}$

A major finding of our study is that physical activity was a significant and independent protective factor, even after adjusting for family history and for the interaction of residence area and diet quality. These findings are consistent with those from previous studies suggesting that the pathogenesis of MS is largely attributable to dietary factors and physical activity. Lack of physical activity or a sedentary lifestyle plays an important role in the development of $\mathrm{MS}^{37}$ and this also applies to our study population. Tobacco con- sumption only showed a weak and non-significant association with MS, and the homogeneity of the sample in this regard may provide a partial explanation. It should also be mentioned that alcohol consumption was not assessed in our study.

Urban subjects showed a higher prevalence of MS $(45.4 \%)$, compared to those living in rural areas (27.6\%). Among urban participants, those living in poor and in rich areas (but not in the intermediate category neighborhoods) were at significantly higher odds of MS than rural men, even after adjusting for age and family history of diabetes.

Anthropometric measurements showed a gradient of higher values with increasing social level of residential area. Rural subjects and urban poor men had the shortest height, while urban rich had the highest. It has been shown that nutritional status during the first years of life is an important factor contributing to final height. ${ }^{38,39}$ A shorter height may reflect a compromised nutritional status in early life, which increases the risk of developing the MS phenotype. ${ }^{40,41}$ Indeed, some studies have shown that final height is inversely related to insulin resistance, diabetes mellitus and cardiovascular disease. ${ }^{42,43}$ In our study, however, we cannot totally exclude some confounding of adult height with ethnicity related to different levels of genetic ad- 
Table V

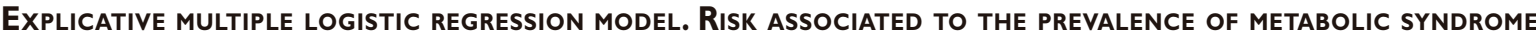 BY RESIDENTIAL AREA AND LIFESTYLE ( $\mathrm{N}=325 \mathrm{MEN}) *$}

\begin{tabular}{|c|c|c|c|c|c|c|}
\hline Factors & Total (n) & $\begin{array}{c}\text { Model: I } \\
\text { OR }(95 \% \mathrm{Cl}) \\
\text { Including only residence } \\
\text { area and diet score }\end{array}$ & p & $\begin{array}{c}\text { Model: II } \\
\text { OR }(95 \% \mathrm{Cl}) \\
\text { I plus family history } \\
\text { of diabetes }{ }^{\ddagger}\end{array}$ & p & $\begin{array}{c}\text { Model: III } \\
\text { OR }(95 \% \mathrm{Cl}) \\
\text { II plus family history of } \\
\text { diabetes and lifestyle }\end{array}$ \\
\hline \multicolumn{7}{|c|}{ Family history of diabetes } \\
\hline No & 208 & & & 1.00 & & 1.00 \\
\hline Yes & 117 & & & $2.13(1.29,3.52)$ & 0.003 & $1.98(I . \mid 8,3.3 I)$ \\
\hline
\end{tabular}

\begin{tabular}{|c|c|c|c|c|c|c|c|}
\hline esidential area ${ }^{\S}$ "preventive" diet score & & & & & & & \\
\hline Rural ${ }^{\S}$ high diet quality index & 136 & 1.00 & & 1.00 & & 1.00 & \\
\hline Urban poor ${ }^{\S}$ low diet quality index & 24 & $3.21(1.34,7.70)$ & 0.009 & $3.04(1.24,7.45)$ & 0.015 & $2.52(1.01,6.32)$ & 0.049 \\
\hline Urban poor ${ }^{\S}$ average diet quality index & 26 & $2.78(1.13,6.82)$ & 0.026 & $2.43(0.96,6.1 \mathrm{I})$ & 0.060 & $1.98(0.77,5.07)$ & 0.155 \\
\hline Urban middle§ low diet quality index & 36 & $1.36(0.70,2.64)$ & 0.290 & $1.28(0.57,2.60)$ & 0.492 & $0.99(0.48,2.04)$ & 0.985 \\
\hline Urban middle ${ }^{\S}$ average diet quality index & 46 & I.48 $(0.72,3.07)$ & 0.359 & $1.22(0.57,2.60)$ & 0.614 & $0.88(0.39,1.97)$ & 0.757 \\
\hline Urban rich§ low diet quality index & 32 & $5.00(1.97,12.60)$ & 0.001 & $4.80(1.86,12.42)$ & 0.001 & $3.15(1.51,8.59)$ & 0.025 \\
\hline Urban rich $^{\S}$ average diet quality index & 25 & $3.35(1.06,5.24)$ & 0.036 & $2.12(0.92,4.89)$ & 0.078 & $\mathrm{I} .44(0.59,3.5 \mathrm{I})$ & 0.424 \\
\hline
\end{tabular}

Physical activity Score

\begin{tabular}{lrrr} 
Low $(\leq 7)$ & 90 & 1.00 & \\
\hline Average $(8$ to 10$)$ & 155 & $0.77(0.44,1.35)$ & 0.364 \\
\hline High $(\geq 1 \mathrm{II})$ & 80 & $0.40(0.19,0.86)$ & 0.018
\end{tabular}

* Estimated odds ratio (OR), confidence interval $(95 \% \mathrm{Cl})$ and level of statistical significance $(\mathrm{P})$

¥ Models I, II and III were adjusted by age and family history of diabetes

$\S$ Interaction

Model I: Hosmer and Lemeshow test: (p) 0.426; area under curve: 0.876, Cl (95\%): 0.829, 0.924

Model II: Hosmer and Lemeshow test: (p) 0.59I; area under curve: $0.884, \mathrm{Cl}(95 \%): 0.835,0.93$ I

Model III: Hosmer and Lemeshow test: (p) 0.676; area under curve: $0.89 \mathrm{I}, \mathrm{Cl}(95 \%): 0.845,0.939$

mixture with native Indians, who are notoriously short. ${ }^{44}$ Rural men were shorter, and they also have a lower BMI and WC. For rural people in southern Mexico, access to food is often limited because of lack of resources. ${ }^{45}$ This may contribute to a better metabolic profile (insulin, HOMA, TG, HDL-Cholesterol) through a more "protective" diet, not by choice but necessity.

We examined the effects of diet on MS controlling for age and family history of diabetes. Poor and rich urban subjects whose diet is low on the prevention scale presented a greater risk of MS compared to rural subjects with a high diet quality index. It is known that a high fat diet can contribute to the development of MS, ${ }^{46,47}$ as is also the case for a high sugar intake. ${ }^{48}$

The $35.5 \%$ rate of abdominal obesity (waist circumference $\geq 94 \mathrm{~cm}$ ) is impressive, in view of its relationship with metabolic alterations of MS. ${ }^{78}$ In a recent national study, the cut-off points for BMI and WC to identify the risk of diabetes mellitus in the Mexican male population were even lower than international values (24 for BMI and $88.8 \mathrm{~cm}$ for WC) ${ }^{49}$ For hypertension the cut-off values were 24.2 and $87.4 \mathrm{~cm}$ for BMI and $\mathrm{WC}$, respectively. It was proposed that the ideal BMI is less than 22 and ideal WC is less than $83 \mathrm{~cm}$, in men. ${ }^{49}$ According to these limits, it can be said that a very high proportion of the urban population, regardless its socio-economic status, is at high risk for diabetes and hypertension.

One strength of this study is the significant preventive role of physical activity which was observed in Mexican men vis-à-vis MS. The cross-sectional nature of the study and the exclusion by design of people with already diagnosed diabetes may be considered study weaknesses. Finally, the size of the sample was not sufficient to manage the interactions with the number of factors analyzed in the multiple logistic regression models.

The prevalence of MS in this study was very high, particularly in the rich or poor urban subjects. Rural subjects may still be protected by a more active life- 
style and possibly also by a lower access to processed, energy-dense industrial foods. The results predict a very devastating epidemiological panorama for Mexico and other countries at similar stages of the nutrition transition, unless appropriate preventive measures are implemented. Similar preventable factors of CVD risk have been observed worldwide. ${ }^{50}$ These factors are primarily healthier eating and greater physical activity, as emphasized by WHO in its 2004 strategy. ${ }^{51}$

Health and nutrition education of the urban Mexican population is compelling, and the role of health institutions in this regard is critical. Perhaps even more urgent is urban planning allowing for greater physical activity, as well as for better transportation and for leisure time recreational activities, even in poorer neighborhoods. This investment would be much smaller than the massive economic burden associated with an escalating rate of obesity and associated health problems.

\section{Bibliography}

I. Reilly MP, Rader DJ.The metabolic syndrome: more than the sum of its parts? Circulation 2003;108:1546-1551.

2. Lakka H-M, Laaksonen DE, Lakka TA, Niskanen LK, Kumpusalo E, Tuomilehto J, et al.The metabolic syndrome and total and cardiovascular disease mortality in middle-age men. JAMA 2002;288:2709-2716. 3. Alberti KG, Zimmet PZ. Definition, diagnosis and classification of diabetes mellitus and its complications. Part I: diagnosis and classification of diabetes mellitus, provisional report of a WHO consultation. Diabet Med 1998;15:539-553.

4. Executive Summary of The Third Report of The National Cholesterol Education Program (NCEP) Expert Panel on Detection, Evaluation, And Treatment of High Blood Cholesterol In Adults (Adult Treatment Panel III). JAMA 200I;285:2486-2497.

5. Balkau B, Charles MA. Comment on the provisional report from the WHO consultation. European Group for the Study of Insulin Resistance (EGIR). Diabet Med 1999;16:442-443.

6. Alberti KG, Zimmet P, Shaw J, The metabolic syndrome - a new worldwide definition. Lancet 2005;366:1059-1062.

7. Carr DB, Utzschneider KM, Hull RL, Kodama K, Retzlaff BM, Brunzell JD, et al. Intra-abdominal fat is a major determinant of the National Cholesterol Education Program Adult Treatment Panel III criteria for the metabolic syndrome. Diabetes 2004;53:2087-2094.

8. Pouliot MC, Després JP, Lemieux S, Moorjani S, Bouchard C, Tremblay A et al.Waist circumference and abdominal sagittal diameter: best simple anthropometric indexes of abdominal visceral adipose tissue accumulation and related cardiovascular risk in men and women. Am J Cardiol 1994:73:460-468.

9. Groop L. Genetics of the metabolic syndrome. Br J Nutr 2000;83 Suppl I:S39-S48.

10. Lidfeldt J, Nyberg P, Nerbrand C, Samsioe G, Schersten B, Agardh $\mathrm{CD}$. Socio-demographic and psychosocial factors are associated with features of the metabolic syndrome: the Women's Health in the Lund Area (WHILA) study. Diabetes Obes Metab 2003;5:106-II2.

II. Hales CN, Barker DJP.The thrifty phenotype hypothesis. Br Med Bull $2001 ; 60: 5-20$.
12. Torjesen PA, Birkeland KI, Anderssen SA, Hjermann I, Holme I, Urdal P. Lifestyle changes may reverse development of the insulin resistance syndrome. The Oslo Diet and Exercise Study: a randomized trial. Diabetes Care 1997;20:26-31.

13. Eriksson J, Taimela S, Koivisto VA. Exercise and the metabolic syndrome. Diabetologia 1997;40:125-I35.

14. Wareham NJ, Hennings SJ, Byrne CD, Hales CN, Prentice AM, Day NE. A quantitative analysis of the relationship between habitual energy expenditure, fitness and the metabolic cardiovascular syndrome. $\mathrm{Br}$ J Nutr 1998;80:235-241.

15. Olaiz G, Rojas R, Barquera S, Shamah T,Aguilar C, Cravioto P, et al. Encuesta Nacional de Salud 2000. Tomo 2 La salud de los adultos. Cuernavaca, Morelos, México: INSP, 2003.

16. Rivera JA, Barquera S, Campirano F, Campos I, Safdie M, TovarV. Epidemiological and nutritional transition in Mexico: rapid increase of non-communicable chronic diseases and obesity. Public Health Nutrition 2002;5: I 13-122, Estadísticas vitales, Daños a la Salud y Mortalidad. México, Dirección General de Estadística e Informática. Secretaría de Salud, 2002.

17. Frenk J, Frejka T, Bobadilla JL, Stern C, Lozano M, Sepúlveda J, et al. The epidemiologic transition in Latin America [in Spanish]. Bol Oficina Sanit Panam I99I; I I (6):485-496.

18. Hernandez-Diaz S, Peterson K, Dixit S, Hernandez-Prado B, Parra S, Barquera $S$, et al.Association of maternal short stature with stunting in Mexican children: common genes vs common environment. Eur J Clin Nutr 1999;53:938-945.

19. Drewnowski A, Popkin BM. The nutrition transition: new trends in the global diet. Nutr Rev 1997;55(2):31-43.

20. Peña M, Bacallao J. Obesity and poverty: an emerging problem in the Americas. In: Peña MaBJ, ed. Obesity and Poverty: A New Public Health Challenge. PAHO Scientific Publication No. 576. Washington, DC: Pan American Health Organization, 2000;132.

21. Harpham T, Stephens C. Urbanization and health in developing countries. World Health Stat Q 1991;44:62-69.

22. Popkin BM. The nutrition transition in low-income countries: an emerging crisis. Nutr Rev 1994;52:285-298

23. Zamora-Gonzalez J, Yamamoto-Kimura L, Lerman-Garber I, Gardoso-Saldaña G, Fajardo-Gutierrez A, Posadas-Romero C. Clustering of metabolic disorders and hyperinsulinemia in Mexico City. Int J Obesity 1996;20:31I-318.

24. Instituto Nacional de Estadística, Geografía e Informática. XI Censo de población y vivienda. México: INEGI, 1990.

25.Villalvazo-Peña P, Corona-Medina JP, García-Mora S. Urbano-rural, constante búsqueda de fronteras conceptuales. Revista de información y análisis 2002;20:17-24.

26. Matthews D, Hosler JP, Rudenski AS, Naylor BA, Treacher DF, Turner R. Homeostasis model assessment: Insulin resistance and B-cell function from fasting plasma glucose and insulin concentration in man.

Diabetologia 1985;28:412-419.

27. Ford ES, Giles WA. Comparison of the Prevalence of the Metabolic Syndrome Using Two Proposed Definitions. Diabetes Care 2003;26: 575-58I.

28. Daveluy C, Pica L, Audet N, Courtemanche R, Lapointe F. Enquête sociale et de santé 1998, 2nd edition. Québec: Institut de la statistique du Québec, 2000.

29. Gibson RS. Principles of nutritional assessment. New York: Oxford University Press, 1990.

30. Food and Agriculture Organization/World Health Organization. Expert Consultation, Diet, nutrition and the prevention of chronic diseases. Geneva:WHO, 2003: I-108.

3I. Breslow NE, Day NE. Statistical methods in cancer research, Lyon: International Agency for Research on Cancer, 1987.

32. Ford E, Giles W, Dietz W. Prevalence of the metabolic syndrome among US adults. JAMA 2002;287:356-359. 
33. Aguilar-Salinas CA, Rojas R, Gómez-Pérez FJ,Valles V, Ríos-Torres JM, Franco A, et al. High prevalence of metabolic syndrome in Mexico. Arch Med Res 2004;35:76-8I.

34. Lorenzo C, Williams K, Gonzalez-Villalpando $C$ and Haffner SM. The Prevalence of the Metabolic Syndrome Did Not Increase in Mexico City Between 1990-1992 and 1997-1999 Despite More Central Obesity. Diabetes Care 2005;28:2480-2485.

35. Hunt KJ, Heiss G, Sholinsky PD, Province MA, FHS Investigators. Familial History of Metabolic Disorders and the Multiple Metabolic Syndrome:The NHLBI Family Heart Study. Genet Epidemiol 2000; 19:395-409.

36. Ekoé JM, Thomas F, Balkau B, Eschwege E, Delisle H. Effect of maternal diabetes on the patterns of selected insulin resistance syndrome parameters in normal glucose tolerant subjects of two Algonquin Indian communities in Quebec. Diabetes Care 1996;19:822-826.

37. Irwin ML, Ainsworth BE, Mayer-Davis EJ,Addy CL, Pate RR, Durstine JL. Physical activity and the metabolic syndrome in a tri-ethnic sample of women. Obes Res 2002;10:1030-1037.

38. Norgan NG. Long-term physiological and economic consequences of growth retardation in children and adolescents. Proc Nutr Soc 2000;59:245-256.

39. Wadsworth MEJ, Hardy RJ, Paul AA, Marshall SF, Cole TJ. Leg and trunk length at 43 years in relation to childhood health, diet and family circumstances; evidence from the 1946 national birth cohort. Int J Epidemiol 2002;31:383-390.

40. Boney CM,Verma A, Tucker R,Vohr BR. Metabolic syndrome in childhood: Association with birth weight, maternal obesity, and gestational diabetes mellitus. Pediatrics 2005; I I5:e290-296.

4I. Li C, Johnson MS, Goran MI. Effects of Low Birth Weight on Insulin Resistance Syndrome in Caucasian and African-American Children. Diabetes Care 2001;24:2035-2042.

42. Leger J, Levy-Marchal C, Bloch J, Pinet A, Chevenne D, Porquet D, et al. Reduced final height and indications for insulin resistance in 20 year olds born small for gestational age: regional cohort study. Br Med J 1997;315:341-347.

43. Smith GD, Greenwood R, Gunnell D, Sweetnam P,Yarnell J, Elwood P. Leg length, insulin resistance, and coronary heart disease risk:The Caerphilly Study.J Epidemiol Community Health 200 I;55:867-872. 44. Malina RM, Buschang PH, Aronson WL, Selby HA. Aging in selected anthropometric dimensions in a rural Zapotec-speaking community in the Valley of Oaxaca, Mexico. Soc Sci Med 1982;16:217-222.

45. Rivera JA, Sepulveda-Amor J. Conclusions from the Mexican National Nutrition Survey 1999: translating results into nutrition policy. Salud Publica Mex 2003;45 Suppl 4:S565-S575.

46.Vessby B. Dietary fat, fatty acid composition in plasma and the metabolic syndrome. Curr Opin Lipidol 2003;14:15-19.

47. Warensjo E, Sundstrom J, Lind L, Vessby B. Factor analysis of fatty acids in serum lipids as a measure of dietary fat quality in relation to the metabolic syndrome in men. Am J Clin Nutr 2006;84:442-448. 48. Liu S, Manson JE. Dietary carbohydrates, physical inactivity, obesity, and the 'metabolic syndrome' as predictors of coronary heart disease. Curr Opin Lipidol 200 I;12:395-404.

49. Sánchez-Castillo CP,Velázquez-Monroy O, Berber A, Lara-Esqueda A, Tapia-Conyer R, James WPT. Anthropometric cutoff points for predicting chronic diseases in the Mexican National Health Survey 2000. Obesity Research 2003; I I:442-445.

50. Yusuf S, Hawken S, Ounpuu S, Dans T,Avezum A, Lanas F, et al. Effect of potentially modifiable risk factors associated with myocardial infarction in 52 countries (the INTERHEART study): case-control study. Lancet 2004;364:937-952.

5I. WHO. Global Strategy on Diet, Physical Activity and Health. Resolution WHA57.17, 2004. R I7-en.pdf» Available in: http:// www.who.int/gb/ebwha/pdf_files/WHA57/A57_RI7-en.pdf. 